\title{
A Financial Management Tool for Sport Federations
}

\author{
Mathieu Winand ${ }^{1}$, Thierry Zintz ${ }^{2}$ and Jeroen Scheerder $^{3}$
}

${ }^{1}$ School of Sport, University of Stirling, UK

${ }^{2}$ Olympic Chair in Management of Sport Organizations, Université catholique de Louvain, Belgium

${ }^{3}$ Research Unit of Social Kinesiology \& Sport Management, University of Leuven, Belgium

Correspondence concerning this paper should be addressed to Dr. Mathieu Winand, School of Sport, University of Stirling, UK, FK9 4LA.

E-mail: Mathieu.Winand@stir.ac.uk

\section{Purpose}

This study aims to develop a tool to manage financial performance of sport federations. It stimulates thinking about the necessity for non-profit sport organisations to develop financial performance measures and management to survive and/or to grow.

\section{Design/methodology/approach}

Adapting the Ritchie and Kolodinsky (2003) model of factor analysis through financial ratios in the sport federation context, we develop a framework for financial performance measurement of sport federations in Belgium for the years 2001 through 2006.

\section{Findings}

Based on a Principal Component Analysis, six financial performance-related categories were constructed, i.e.: (1) public funds dependence; (2) financial balance; (3) attraction of resources; (4) financial budget; (5) member services investment; and (6) elite services 
investment. They form the basis of a dynamic strategic management tool where financial categories are related to each other.

\section{Research limitations/implications}

The financial management tool can be a starting point for further organisational (performance) research. Differences and similarities between countries (e.g., sport policy priorities) and sport organisations (e.g., sport profiles) could be better investigated through our financial performance framework.

\section{Practical implications}

The tool developed should help strategic volunteers and managers of sport federations to take strategic decision relying on financial information in order to pilot their organisation and to communicate with their stakeholders.

\section{Originality/value}

Developing financial performance measurement of non-profit sport organisations is challenging and considerably different from for-profit and non-profit organisations. It provides researchers and practitioners with a viable model for analysing financial strategy and performance of sport federations over time.

Keywords: financial management, financial performance, sport federations, financial management tool

\section{Introduction}

The non-profit sector faces an essential issue that practitioners from the sports movement also deal with. On the one hand, non-profit sporting organisations need financial support from public and private institutions, but on the other hand, they wish independence in organising sporting activities. Therefore, they are willing to receive support, but not to be controlled (Norberg, 1997; Winand et al., 2010). The financial autonomy of these non-profit 
organisations is limited. They are not focused on making profits as is the case in for-profit organisations which are owned by shareholders, but instead they have social and societal purposes. Furthermore, non-profit volunteers and workers are motivated more by societal changes and recognition and less by money (Mirvis et al., 1991; Smith, 2000). Financial considerations are still taboo in non-profit organisations regarding to which extent they should analyse and measure the organisation's financial performance. Notwithstanding the fact that making financial profit is not a goal for non-profit organisations, they do have economic concerns and can generate financial profit as long as they invest it through their services (Hull and Lio, 2006; Sandler and Hudson, 1998). Thibault et al. (1993) underlined that resources are critical to non-profit sport organisations such as national sport federations. Despite its crucial interest in strategic management, financial performance measurement of sport federations remains elusive. Yet, no agreement about ratios or financial performance-related categories has emerged which would give scholars and practitioners a tool to take strategic decisions relying on financial information.

This paper aims to develop a tool to manage financial performance of sport federations. As a result, we identify distinct financial performance-related categories grouped into a financial performance framework for sport federations. Several reasons emerge for the importance of the current study. In line with Keating and Frumkin (2001), we assume (1) that measuring non-profit financial performance helps to determine how effective and efficient the organisation is in fulfilling its mission. Source of funding, cost of services and leeway of the organisation to operate in the future are crucial information for strategic management. The tool we develop might (2) help strategic volunteers (and paid managers) of sport federations to take strategic decisions in highlighting the strengths and weaknesses of their organisation. Also, at present time, financial analysis is needed (3) to avoid financial scandals (embezzlement, fraud, corruption, etc) and helps a better transparent communication to 
stakeholders. These main motives make the financial management tool critical for non-profit (sport) organisations.

The paper is structured as follows. First, a review of studies measuring financial performance in sport federations is presented in order to highlight relevant financial ratios and concepts. According to Gerrard (2004, p.164), the computation of selected ratios using financial information "is a very convenient means of summarizing and evaluating a large volume of information". Secondly, we present the methodology to measure financial performance of 56 sport federations in Belgium from 2001 to 2006. Thirdly, results show the financial performance categories resulting from the factor analysis which make up the financial management tool. Finally, we discuss the relationships between the financial categories and provide practical and research implications of these findings.

\section{Literature review}

Financial capacity of a for-profit organisation is defined as the ability and potential to develop and deploy financial capital one can convert into money: revenues, expenses, assets, liabilities (Bourdieu, 1986; Hall et al., 2003). Thus, financial performance could be viewed as the development of the financial capacity of an organisation over time. However, depending on the organisation goals, the targeted financial capacity will be different. Multiple criteria should be used to understand and measure financial performance for both non-profits and forprofits. Whereas for-profit organisations would mainly define and measure financial performance according to operating margin, total margin, return on assets, return on investment, profitability, benefits, etc., non-profit organisations will focus on financial stability, balanced budget, funding goals, etc. Even if the latter might be not-for-profit, they are not-for-loss either (Casteuble, 1997). It is the reason why non-profit financial performance is crucial for their survival and of interest to be analysed. Gerrard (2004) put forward three roles financial performance analysis could fulfil within a sport organisation, namely: (1) the 
identification of key financial information; (2) the measurement of financial values; and (3) the communication to the organisation's stakeholders. However, sport organisations are acting for different purpose which might have an impact on the use of financial information. Indeed, the sports movement include two main different types of sport organisations, professional/commercial and amateur/non-profit sport organisations, for which response to financial performance is radically different. Because it is not always clear to which type a sport organisation belongs (e.g., professional sport clubs having non-profit status), we believe it is necessary to specify that we focus on sport federations which are generally non-profit oriented. They develop and promote their sport as their main goal. Their resources are directly linked to the development of sport activities and competitions for their members. Their ability to attract financial resources from external sources is considered a strategic imperative (Thibault et al., 1993). Therefore, their financial performance might be considered a central topic for long-term sustainability (Harrison and Sexton, 2004).

For these organisations, accumulating financial resources acts counter to their goals (Bayle, 1999; Smith, 2000). Furthermore, their financial dependence on external agencies “often limits their flexibility in initiating strategic planning” (Thibault et al., 1993, p.26). In some countries like Canada, which has a 'non-profit sports culture' and a strong research tradition on voluntary sport organisations, authorities have linked financial contributions to specific public policy objectives (Kihl et al., 2007). With the non-profit objectives, a significant indicator of a non-profit orientation is the source of funding that sustains the organisation. Kimberly and Rottman (1987) suggested that the weight of the different kind of financial support could have an influence on the organisation direction. The financial contribution of authorities is one of the key aspects of the financial performance of these organisations which contrasts with profit oriented organisations. For sport federations, funding vary between membership fees, fund raising, sponsorship financial support, unconditional grants and grants affected to specific objectives (Kikulis et al., 1992). The 
balance between these resources influences the organisation strategy (its objectives, activities and structure) and values its non-profit orientation (Kikulis et al., 1992). All these reasons call for the development of a specific financial performance management tool for sport federations and non-profit sport organisations in general, no matter their size and sport (Gerrard, 2004).

Slack (1998) suggested that sport federations (namely, Canadian national sport organisations) which have been the least successful to replace state funding with corporate financial support might show signs of returning to the 'kitchen table' type of design underlined by Kikulis et al. (1992). This organisational design shows a handful of charismatic volunteers who manage the policies, programs and finances of the organisation with little planning and informal rules, regulations, decision making and communication. This is the type of policy-making that is used in the sport federations we investigate in Belgium (e.g., ad hoc, incremental way of making policy). Although this design is not necessarily bad for all of them, it demonstrates a lack of stability when facing changing funding which does not augur well for their future (Slack, 1998). Thus, financial management is of organisational and strategic relevance due to its influence on organisational design (Slack and Thibault, 1988). The financial management tool developed in this paper can consequently identify issues of organisational importance. No matter the size, objectives, sport or structure of sport federations, it can provide their strategic volunteers and paid managers information to evaluate and pilot their organisation.

Specific research on financial performance of non-profit sport organisations is considered to be rare (e.g., Késenne, 2006; Stewart, 2007). It is often difficult to collect and have a clear understanding of their financial accounts. Indeed, collecting detailed financial information for these organisations is sometimes a real challenge when no clear and transparent financial documents are available. Furthermore, the ratios often used (e.g., liquidity, solvability, profitability, cash flow, financial balance, etc) are most of the time not specific to the non-profit organisation context. They might not be sufficiently detailed to 
allow a comprehensive financial analysis of sport federations (e.g., elite sport expenditures versus sport for all expenditures).

Due to the fact that financial performance is one of the key dimensions of organisational performance in sport federations (Winand, 2009; Winand et al., 2010), research using financial analysis in the sport management literature has been included into organisational performance studies. These studies used actors' perceptions (Balduck, 2009; Chelladurai et al., 1987; Koski, 1995; Papadimitriou and Taylor, 2000; Shilbury and Moore, 2006; Wolfe, Hoeber and Babiak, 2002), financial data (Bayle and Madella, 2002; Frisby, 1986; Madella et al., 2005; Papadimitriou, 2002) or both (Winand et al., 2010) to understand, highlight or measure the financial performance dimension within the whole organisation context. They highlighted specific categories we reduced into four. Financial independence (1) represents the possible resources diversification of non-grants resources and the selffinancing capacity. Financial goal (2) includes financial stability and balance. Financial resources acquisition (3) was the most common category underlined by researchers. It concerns attraction of financial resources. Financial resources management (4) refers to the distribution of funding stream, cost structure and allocation of resources.

These four financial performance categories are in line with the categories highlighted in the non-profit literature (Ritchie and Kolodinsky, 2003; Ritchie et al., 2007). Nevertheless, the measurement provided by the aforementioned researchers in the sport management literature for each category is limited and lack convergence. None has taken into account all these dimensions to provide a tool to analyse sport federation financial performance.

Using factor analysis, Ritchie and Kolodinsky (2003) developed a process for evaluating financial performance measures in the non-profit sector. They analysed four performance-related categories for university foundations, i.e.: (1) public support; (2) fiscal performance; (3) fundraising efficiency; and (4) investment performance. The public support category is related to an organisation ability to obtain public funds. It is an index of its 
financial (in)dependence. Fiscal performance refers to ratios of revenues to expenses which highlight financial profit, loss or balance. Financial balance is, at least, the objective of nonprofit organisations. Fundraising efficiency focuses on ratios relating outputs to inputs (Berman, 1998; Ritchie and Kolodinsky, 2003) that is money raised in comparison to money spent on fundraising activities. This deals with the ability to attract sufficiently high resources to cover the expenses needed to attract them. Investment performance concerns ratios involving marketable securities. However, in sport federations, this category would better concern expenses and allocation of resources to develop services for their members, as it is part of their mission.

We adapt the categories from the non-profit organisation literature to highlight four $a$ priori main financial performance-related categories for sport federations, namely: (1) public funds dependence, (2) financial balance, (3) attraction of resources, and (4) services investment.

\section{Methodology}

Ritchie and Kolodinsky (2003) evaluated the financial performance of university foundations through financial ratios based on Siciliano (1996, 1997) and Greenlee and Bukovinsky (1998). The advantage of their method is the possibility to conduct a longitudinal quantitative analysis. In the present study we adapt their method to the financial analysis of all the 56 Olympic, non-Olympic and leisure-time French speaking sport federations in Belgium. Most of the Belgian sport federations have had to split to obtain grants from their regional governments. Flemish sport federations are no part of the present study. French speaking sport federations take strategic and daily decisions to organise, to develop and to promote their sport like national sport federations in other countries. We have collected their financial accounts for the years 2001 through 2006 in the French speaking sport administration. In line with the financial standardisation model developed by Zintz (2004) for Belgian sport 
federations, we were allowed to compare their financial accounts. Also, we used the 2005 index of consumer prices from the Belgian Institute of Statistics in order to compare the different years. Twenty-seven of the fifty-six sport federations promote an Olympic sport, with only two winter sports (ski and figure skating). The two Olympic winter sport federations might have very low impact on sport policy, if any, during the Winter Olympic Games in comparison with Olympic summer sport federations during Summer Olympic Games.

According to the literature, we computed fifteen financial ratios which are a priori attributed to one of the four financial performance-related categories highlighted in the literature: (1) public funds dependence (public resources divided by the total revenue and divided by the total expenses); (2) financial balance (net revenues divided by total revenue, total revenue divided by total expenses, net revenues); (3) attraction of resources (total revenues, grants per member, total revenues per member, revenues from member per member, sponsorship revenue divided by the total revenue); and (4) services investment (total expenses, non-management expenses divided by the total expenses, members and elite services investment divided by the total expenses, membership financial return). In line with the literature, we assume these financial ratios give a clear overview of the financial performance of sport federations. Ratios of the attraction of resources and services investment categories slightly differ from what has been suggested by Ritchie and Kolodinsky (2003) when they studied university foundations (namely fundraising efficiency and investment performance). Ratios of the attraction of resources category are related to the size of sport federations in order to adjust their ability to attract resources. Ratios of the services investment category are related to expenses and investments for members instead of securities which do not appear to be a priority for sport federations according to their financial account analysis. 
We used factor analysis to identify patterns in the financial ratios and to reduce them into a structured handful of categories (Hair et al., 1998) which constitutes the financial management tool. Principal Component Analysis (PCA) with promax rotation was used to reveal the financial performance-related categories, in line with Ritchie and Kolodinsky (2003). We performed PCA with promax rotation for each year (2001-2006) using the software SPSS. Then, standard normalisation (using standard deviations as references) provided us with a score for each financial ratio. Average performance scores of the financial ratios associated to a specific category were computed to obtain a score for each financial performance-related category for years 2001 to 2006. The higher a performance score, the more a sport federation performed in a specific category for a specific year. This allows assessing each sport federation with one another for a 6-year time period. The tool might thus be reliable over time. Finally, correlational analysis between categories was performed using Pearson correlations with SPSS software. Relationships between categories were analysed for each year. Hence, analysis of the relationships of the financial performance-related categories over time is possible.

\section{Results}

Fifteen financial ratios were computed for each of all the 56 sport federations for the years 2001 to 2006. Exactly 4,572 financial ratios were computed. Only 9.3 percent of all possible financial ratios (i.e., 5,040 ratios) could not be calculated due to a lack of data. We assume we obtained a sufficient number of financial ratios to give a clear overview of the financial performance of the French speaking sport federations in Belgium for 2001 to 2006.

$$
\text { Insert Table } 1 \text { about here }
$$

Table 1 shows the median and the minimum and maximum values of all of the fifteen financial ratios for 2001 and 2006. It gives an overview of the values (in percentage or euro) of the financial ratios for all sport federations measured, their dispersion and their evolution in 
the 6-year time period of analysis. The median values of the percentage of public resources compared to total revenue are high and increase from 2001 (48 percent) to 2006 (52 percent). According to Winand et al. (2010), a majority of sport federations in Belgium are financially dependent towards public funding. Furthermore, about half of their expenses were covered by public funds. When taking these values as references, this would suggest that their selffinancing capacity was weak. Nonetheless, the financial ratios between revenues and expenses show that most sport federations made a few benefits (which had to be invested in their activities), except for 2002 (-0.5 percent). Several sport federations had difficulties in attaining financial balance, especially in 2002. Attraction of grants and revenues divided by the number of members seems particularly high and increased from 2001 to 2006. Nonetheless, this is especially true for small sized sport federations receiving non conditional grants for all their activities, included their management expenses. The total median revenues increased by 72.5 percent from 2001 to 2006 . The minimum and maximum values for these financial ratios attest the discrepancy between sport federations regarding attraction of resources. Considering sponsorship revenues, the results show that they were weak from 2001 to 2006. Indeed, the median percentages of sponsorship revenues stay below 2 percent. Sponsorship revenues attraction seems to be a common shared weakness for a majority of French speaking sport federations in Belgium. Total expenses of sport federations also increased from 2001 to 2006. Investment in services to members and general nonmanagement expenses remained stable whereas elite services expenditure increased. Finally, sport federations allocated around half of the resources coming from their members to develop and to organise activities for the latter (membership financial return).

Insert Table 2 about here

Table 2 shows minimum and maximum coefficients of Principal Component Analysis (PCA) for the years 2001-2003 and 2005-2006. PCA for the year 2004 slightly differs from the five other years. For the years 2001-2003 and 2005-2006 (Table 2), six financial 
performance-related categories emerge (significance >.4), i.e.: (1) public funds dependence; (2) financial balance; (3) attraction of resources; (4) financial budget; (5) member services investment; and (6) elite services investment. Twelve financial ratios are significantly measuring these categories (excluding $\mathrm{R}_{5,12,10}$ ). Public funds dependence is measured by ratios of financial dependence (public resources divided by total revenue) and self-financing capacity (public resources divided by total expenses). Public funds dependence measures to which extend sport federations receive public support. Financial balance is measured by ratios of benefits (total revenue divided by total expenses) and benefits in comparison with revenues (net revenues divided by total revenue). Financial balance measures the financial stability of sport federations regarding losses, profits and percentage of revenues not spent. It is also indicators of its financial stability over time. Attraction of resources is measured by ratios of revenues adjusted to the organisation's number of members (grants per member, total revenues per member and revenues from member per member). Attraction of resources measures the 'net' (adjusted to the size) ability of sport federations to attract revenues. Financial budget is measured by ratios of total revenues and expenses. It measures the funds of sport federations which are proportional to their size. Generally speaking, more members and staff require and give the possibility to obtain more resources. Member services investment is measured by ratios of percentage of expenses for member services (services for members investment divided by total expenses) and percentage of expenses allocated to members in comparison with resources received from the latter (membership financial return). Member services investment measures to which extend sport federations invest in membership activities and services. Elite services investment is measured by the percentage of elite expenses (elite services investment divided by total expenses). It measures to which extent sport federations invest in elite services and support.

The major difference for the year 2004 results in the fusion between public funds dependence and elite services investment categories. For 2004 - year of the Summer Olympic 
Games in Athens - the ratios measuring these two distinct financial performance-related categories significantly belong to a single category. Thus, a relationship might exist between public funds dependence and elite services investment. In analysing the performance score for each category and following the six performance related categories highlighted for five of the six years studied, we observed correlations between the different financial performancerelated categories. Table 3 indicates these correlations.

Public funds dependence and elite services investment are significantly correlated between years 2003 and 2006 (from r=.34 to $r=.38$ with a coefficient of correlation of .52 in 2004). This indicates that the ability of sport federations to invest in elite sport is proportional to the public resources they receive. For 2004, financial balance is correlated negatively $(\mathrm{r}=-$ 0.54) with member services investment and positively $(r=.4)$ with elite services investment. The latter competes with member services investment for 2003 (r=-0.31) and for 2004 ( $r=-$ 0.4). This denotes that relative net revenues of sport federations which invest in elite sport were higher than sport federations which invest in sport for all activities. However, in 2002, financial balance and elite services investment are correlated negatively $(\mathrm{r}=-0.34)$. Therefore, for this year, investing in elite sport might lead to less relative net revenues. The 2004 Olympic Games might have an impact on the relative net revenues of sport federations investing in elite sport. Furthermore, for 2005, financial balance and attraction of resources are correlated positively $(\mathrm{r}=.31)$.

Public funds dependence and financial budget are negatively correlated from 2001 to 2006 (from $r=-0.41$ to $r=-0.38$ ). This means that small sized sport federations obtained relatively (in relative terms, that is percentage of revenues or expenses) more grants compared to large sport federations. In other words, grants received by large sport federations are less important in comparison with their total budget than for small sport federations. Finally, public funds dependence and financial balance are positively correlated from 2001 to 2003 
( $\mathrm{r}=.34$ in 2001, $\mathrm{r}=.51$ in 2002 and $\mathrm{r}=.32$ in 2003) showing that sport federations which received relatively high grants were obtaining more relative revenues (but not net revenues) before the 2004 Olympic Games. This framework results in the development of a financial management tool for sport federations.

\section{Discussion}

Three financial performance-related categories correspond to those found by Ritchie and Kolodinsky (2003): (1) public funds dependence; (2) financial balance (namely fiscal performance); (3) attraction of resources (namely fundraising efficiency). On the other hand, the financial budget category has emerged, whereas the investment of resources category has split. According to Papadimitriou (2002), the former refers to sport federations' financial capacity (total revenues and total expenses) to obtain resources and to allocate them which are directly related to the size (number of members and employees) of sport federations. The investment category has been split up between 'elite' and 'ordinary' member services investment which are competing with one another as suggested by Shilbury and Moore (2006). The increasing public support some sport federations received in 2004 (e.g., sport federations related to an Olympic sport which have elite athlete(s) expected to compete in the 2004 Olympic Games) fits together with their elite services investment. This is also true for the years 2003, 2005 and 2006, but the relationship is stronger in 2004. Despite the fact that we expected public resources to be correlated with member services investment, they are correlated with elite services investment. There might have been a shift in sport policy from a sport for all orientation to elite support. In Belgium, elite successes need support from the public authorities and provide a (extremely valuable but uncertain) return through the reputation of the nation.

Olympic sport federations might increase their elite services investment to reach sport results at the Summer Olympic Games with the support of public authorities. Some sport 
federations have disregarded member services investment in favour of elite sport support in 2003 and 2004. For 2004, they might have generated a much more positive financial balance than the sport federations which did not invest in elite sport as a priority but in sport for all. These results show the great impact the Olympic Games have on the financial performance of sport federations in Belgium and on the (re)definition of their priorities and investments and the elite sport policy which prevail. The public authorities play a crucial role by increasing their support to elite sport through sport federations. Small sport federations might depend more on public support than large sport federations. The results suggest that public funds dependence and financial budget were negatively correlated for the 6-year time period we studied. Thus, sport federations with small budget have greater percentage of public funds in comparison with their total revenues than sport federations with large revenues and expenses. The public funds sport federations receive are crucial to their survival and to the development of their activities. In average, they represent (almost) half of their total revenues. Because sponsorship resources are rare for a great majority of these sport federations, they rely on membership financial support through fees and financial contribution during sport activities. In average, around half of these resources are used for other purposes than member services according to the financial ratio membership financial return.

Sport federations should be able to use the financial management tool developed in this article as they are equipped with sufficient information from their financial accounts to compute the key financial indicators highlighted. Therefore, the tool added value relies on quantitative data each sport federation possesses and their longitudinal analysis. In addition, it helps strategic volunteers and paid managers to bring into focus qualitative elements affecting decision making that may not be expressed in quantitative terms. It provides necessary information to potentially well manage an organisation. In the following section, we illustrate the tool using a case study combined with useful non-financial information. We present the financial performance analysis of the athletics federation according to its performance scores 
on each of the six financial performance-related categories for the 6-year time period (20012006). Figure 1 shows the financial performance of the athletics federation from 2001 to 2006. Due to standard normalisation, the mean for all sport federations investigated equals five for each year.

The athletics federation is a large sized sport federation in comparison with all the French speaking sport federations in Belgium. This Olympic sport federation seemed to be more and more dependent towards public funds through years in comparison with the other sport federations. At the same time, its ability to attract resources decreased in comparison with the other sport federations which might have resulted from an increase of membership figures but no significant increase of resources. In 2004, athletics suffered from a major issue regarding its financial stability. Its financial balance in 2004 attests the financial loss. In 2004, athletics did not receive all the expected resources to invest in elite sport and member services. The performance scores of these categories decrease. However, in 2005, while athletics increased its elite services investment, in line with its public funds dependence, its member services investment still remained weak in comparison with the other sport federations. Finally, the year 2006 shows very high level of financial balance, elite investment and public funds dependence in comparison with the other sport federations measured. Nevertheless, its weakness still remains its member services investment which competes with its elite sport priority. This analysis could be performed for each sport federation in order to measure and monitor their financial performance on different relevant categories over time. Therefore, the tool developed in this research could be applied to pilot sport federations and similar non-profit sport organisations (e.g., large non-profit sport clubs). 


\section{Conclusion}

Through this article, we developed a tool to manage financial performance of sport federations. We collected financial accounts of sport federations in Belgium to compute financial ratios adapted from the literature. Principal Component Analysis of these ratios provide us with six significant and relevant financial performance-related categories, i.e.: (1) public funds dependence; (2) financial balance; (3) attraction of resources; (4) financial budget; (5) member services investment; and (6) elite services investment. This framework provides researchers and practitioners in the field of non-profit sport organisations with a viable tool for analysing financial performance of sport federations over time. It helps to identify trouble in the management of sport federations and to select strategic orientations in the long term according to their own mission and objectives. The positioning of each organisation could be analysed which might highlight weaknesses they could change.

The ability of Belgian sport federations to invest in elite sport is proportional to the public resources they receive. This is particularly true in 2004, the year of the Summer Olympic Games in Athens. Small sized sport federations obtain, in relative terms, more subsidies in comparison with large. The role of the public authorities in elite support is crucial. They might particularly support specific sports. Finally, elite and member services investment compete in sport federations. Some sport federations might have decreased their investments in sport for all to increase their investment in elite sport.

Managerial implication of this study results in the identification of key financial performance categories and the way to measure them. It provides strategic volunteers and paid managers with a strategic financial management tool to measure and to control the financial performance of their sport federation, to pilot it and to communicate with their stakeholders. It may help sport federations to face change and to plan future actions and strategies in line with a more specialised and standardised organisational design (Kikulis et al., 1992; Slack, 1998). 
We illustrated this implication with the example of the athletics federation and the difficulties it faced in the 2004 Olympic year, during which the pressure and importance of Olympic sports is at the highest level. We highlighted strengths and weaknesses of this sport federation over time. The financial performance-related categories highlighted and the financial ratios help to understand what financial performance refers to in the specific context of sport federations and non-profit sport organisations in general. It can be a starting point for further organisational (performance) research as well as for the analysis of high versus low profile sport federations. Indeed, high profile sports are being paid attention from the media, and a great number of people are involved in these and/or informed about them. Their financial performance could substantially differ from low profile sports. Furthermore, further research could confirm the relevant categories highlighted using a case study analysis of a sport federation. Researchers could also investigate the sport policy priorities in different countries between sport for all and elite sport through sport federations and sport clubs funding and the shift to more elite sport support.

The main limitation to be considered is that sport federations are not universally the same despite their similar structures (Hums and MacLean, 2008). Indeed, different operating models exist according to countries (e.g., the United States sport model compared with the European sport model) which may considerably influence their financial performance. Furthermore, the Belgian sport federations investigated in this research are small-scale, so that the findings of this study might not be applicable to all types of sport federations (e.g., large professional or international sport federations).

\section{References}

Balduck, A. (2009), Effectiveness in Sport on Micro and Meso Management Level, Unpublished doctoral dissertation, Universiteit Gent, Gent, Belgium. 
Bayle, E. (1999), Management et performance des organisations à but non lucratif. Le cas des fédérations sportives nationals [Management and performance of non-profit organizations. The case of national sport federations], Unpublished doctoral dissertation, Université de Limoges, Limoges, France.

Bayle, E. and Madella A. (2002), "Development of a Taxonomy of Performance for National Sport Organizations”, European Journal of Sport Science, Vol. 2, No. 2, pp. 1-21.

Berman, E. M. (1998), Productivity in Public and Nonprofit Organizations, Sage, Thousand Oaks, CA.

Bourdieu, P. (1986), “The forms of capital”, in Richardson, J. (Ed.), Handbook of theory and research for the sociology of education, Greenwood, New York, pp. 241-258.

Casteuble, T. (1997), “Using financial ratios to assess performance”, Association Management, Vol. 49, No. 7, pp. 29-36.

Chelladurai, P., M. Szyszlo and Haggerty, T. R. (1987), "System-based dimensions of effectiveness: The case of national sport organizations", Canadian Journal of Sport Science, Vol. 12, No. 2, pp. 111-119.

Frisby, W. (1986), "Measuring the organizational effectiveness of National Sport Governing Bodies", Canadian Journal of Applied Sport Science, Vol. 11, No. 2, pp. 94-99.

Gerrard, W. (2004), "Sport Finance”, in Beech, J. and Chadwick, S. (Eds), The Business of Sport Management, Pearson Education, Edinburgh Gate, pp. 154-190.

Greenlee, J.S. and Bukovinsky, D. (1998), "Financial Ratios for Use in the Analytical Review of Charitable Organizations", Ohio CPA Journal, pp. 32-38.

Hair, J. F., R. E. Anderson, R. C. Tatham and Black, W. C. (1998), Multivariate Data Analysis. (5th ed.), Prentice Hall, Upper Saddle River, N.J.

Hall, M. H., A. Andrukow, C. Barr, K. Brock, M. de Wit and Embuldeniya, D. (2003), The capacity to serve: A qualitative study of the challenges facing Canada's nonprofit and voluntary organizations, Canadian Centre for Philanthropy, Toronto, ON. 
Hargreaves, J. (1986), Sport, power and culture, Polity Press, Oxford.

Harrison, J., and Sexton, C. (2004), “The paradox of the not-for-profit hospital”, Health Care Manager, Vol. 23, No. 3, pp.192-204.

Hull, C. E. and Lio, B. H. (2006), "Innovation in non-profit and for-profit organizations: Visionary, strategic, and financial considerations", Journal of Change Management, Vol. 6, No. 1, pp. 53-65.

Hums, M.A. and MacLean, J. C. (2008), Governance and policy in sportorganizations. (2d ed.), Holcomb-Hathaway, Phoenix, AZ.

Keating, E. K. and Frumkin, P. (2001), How to assess nonprofit financial performance (Kennedy School of Government, Working Paper), Kennedy School of Government, Harvard University, Cambridge, MA.

Késenne, S. (2006), "Financiële doorlichting van de Vlaamse sportfederaties", in: De Knop, P., Scheerder, J. and Ponnet, H. (Eds.), Sportbeleid in Vlaanderen, Bloso/Vlaamse Trainersschool, Brussels, pp. 143-145.

Kihl, L. A., L. M. Kikulis and Thibault, L. (2007), “A Deliberative Democratic Approach to Athlete-Centred Sport: The Dynamics of Administrative and Communicative Power", European Sport Management Quarterly, Vol. 7, No. 1, pp. 1-30.

Kikulis, L. M., T. Slack and Hinings, B. (1992), “Institutionally Specific Design Archetypes: A Framework for Understanding Change in National Sport Organizations", International Review for the Sociology of Sport, Vol. 27, No. 4, pp. 343-368.

Kimberly, J.R. and Rottman, D. B. (1987), “Environment, Organization, and Effectiveness: A Biographical Approach”, Journal of Management Studies, Vol. 24, No. 6, pp. 595-622. Koski, P. (1995), “Organizational effectiveness of Finnish sports clubs”, Journal of sport management, Vol. 9, No. 1, pp. 85-95. 
Madella, A., E. Bayle and Tome, J.-L. (2005), "The organisational performance of national swimming federations in Mediterranean countries: A comparative approach", European Journal of Sport Science, Vol. 5, no. 4, pp. 207-220.

Mirvis, P.H., A. L. Sales and Hackett, E. J. (1991), "The implementation and adoption of new technology in organizations: The impact on work, people, and culture", Human Resource Management, Vol. 30, No. 1, pp. 113-139.

Norberg, J. R. (1997), “A mutual dependency: Nordic sports organizations and the state", International Journal of the History of Sport, Vol. 14, No. 3, pp. 115-135.

Papadimitriou, D. (2002), “Amateur structures and their effect on performance: the case of Greek voluntary sport clubs”, Managing Leisure: An International Journal, Vol. 7, No. 4, pp. 205-219.

Papadimitriou, D. and Taylor, P. (2000), “Organisational Effectiveness of Hellenic National Sports Organisations: A Multiple Constituency Approach”, Sport Management Review, Vol. 3, No. 1, pp. 23-46.

Ritchie W.J. and Kolodinsky, R. W. (2003), “Nonprofit Organization Financial Performance Measurement An Evaluation of New and Existing Financial Performance Measures”, Nonprofit Management \& Leadership, Vol. 13, No. 4, pp. 367-381.

Ritchie, W. J., Kolodinsky, R. W. and Eastwood, K. (2007), “Does Executive Intuition Matter? An Empirical Analysis of Its Relationship With Nonprofit Organization Financial Performance", Nonprofit and Voluntary Sector Quarterly, Vol. 36, No. 1, pp. 140-155.

Sandler, M.W. and Hudson, D. H. (1998), Beyond the bottom line: How to do more with less in nonprofit and public organizations, Oxford University Press, New York.

Shilbury, D. and Moore, K. (2006), “A Study of Organizational Effectiveness for National Olympic Sporting Organizations", Nonprofit and Voluntary Sector Quarterly, Vol. 35, No. 1, pp. 5-38. 
Siciliano, J.I. (1996), “The Relationship of Board Member Diversity to Organizational Performance", Journal of Business Ethics, Vol. 15, No. 12, pp. 1313-1320.

Siciliano, J.I. (1997), “The relationship between formal planning and performance in nonprofit organizations", Nonprofit Management and Leadership, Vol. 7, No. 4, pp. $387-403$.

Slack, T. (1998), "Studying the commercialization of sport: The need for critical analysis", Sociology of Sport On-Line, 1(1), http://physed.otago.ac.nz/sosol/v1i1/v1ila6.htm (December 16, 2010).

Slack, T. and Thibault, L. (1988), "Values and beliefs: Their role in structuring of national sport organizations", Arena Review, Vol. 12, No. 2, pp. 140-155.

Smith, D. H. (2000), Grassroots associations, Sage, Thousand Oaks, CA.

Stewart, B. (2007), Sport Funding and Finance, Butterworth-Heinemann, Oxford.

Thibault, L., Slack T. and Hinings, B. (1993), “A framework for the analysis of strategy in non-profit sport organizations", Journal of Sport Management, Vol. 7, pp. 25-43.

Winand, M. (2009), Déterminants de la performance organisationnelle des fédérations sportives : une analyse comparée des ligues sportives de la Communauté française de Belgique [Determinants of organizational performance in sport federations: a compared analysis of the French speaking sport federations in Belgium], Unpublished doctoral dissertation, Université catholique de Louvain, Louvain-la-Neuve, Belgium.

Winand, M., Zintz, T., Bayle, E. and Robinson, L. (2010), “Organizational performance of Olympic sport governing bodies. Dealing with measurement and priorities”, Managing Leisure: An international Journal, Vol. 15, No. 4, pp. 279-307.

Wolfe, R., Hoeber, L. and Babiak, K. (2002), "Perceptions of the effectiveness of sport organizations: the case of intercollegiate athletics", European Sport Management Quarterly, Vol. 2, No. 2, pp. 135-156. 
Zintz, T. (2004), Configuration et changement organisationnel des ligues et fédérations sportives belges Typologie et perspectives d'évolution [Configuration and organizational change of Belgian sport federations. Typology and future developments], Unpublished doctoral dissertation, Université catholique de Louvain, Louvain-la-Neuve, Belgium. 
Table 1: Median, minimum and maximum values of the financial ratios for 2001 and 2006

\begin{tabular}{|c|c|c|c|c|c|c|}
\hline & \multicolumn{3}{|c|}{2001} & \multicolumn{3}{|c|}{2006} \\
\hline & Median & Min. & Max. & Median & Min. & Max. \\
\hline $\mathrm{R}_{1:}$ Public resources divided by total revenue $(\%)$ & 48.2 & 9.7 & 95.5 & 52.2 & 5.7 & 85.2 \\
\hline $\mathrm{R}_{2:}$ Public resources divided by total expenses (\%) & 49.4 & 9.5 & 146.5 & 54.6 & 6.3 & 102.9 \\
\hline $\mathrm{R}_{3:}$ Total revenue divided by total expenses (\%) & 102.6 & 79. & 177.8 & 102.7 & 89.1 & 129.0 \\
\hline $\mathrm{R}_{4:}$ Net revenues divided by total revenue $(\%)$ & 2.5 & -26.6 & 43.8 & 2.6 & -12.2 & 22.5 \\
\hline $\mathrm{R}_{5:}$ Net revenues $(€)$ & 2,821 & $-96,574$ & 108,423 & 4,859 & $-40,618$ & 242,183 \\
\hline $\mathrm{R}_{6:}$ Total revenues $(€)$ & 157,715 & 13,547 & $2,294,103$ & 272,006 & 10,762 & $3,957,530$ \\
\hline $\mathrm{R}_{7:}$ Grants per member $(€)$ & 24.4 & 0.7 & 98.5 & 30.2 & 0.6 & 199.7 \\
\hline $\mathrm{R}_{8:}$ Total revenues per member $(€)$ & 56.6 & 6.6 & 350.9 & 72.7 & 4.7 & 640.9 \\
\hline $\mathrm{R}_{9:}$ Revenues from member per member $(€)$ & 31.0 & 1.6 & 266.5 & 31.0 & 1.4 & 496.3 \\
\hline $\mathrm{R}_{10:}$ Sponsorship revenue divided by total revenue (\%) & 0.4 & 0.0 & 12.4 & 1.1 & 0.0 & 12.6 \\
\hline $\mathrm{R}_{11:}$ Total expenses $(€)$ & 146,468 & 8,898 & $2,215,467$ & 288,854 & 11,012 & $3,715,347$ \\
\hline $\mathrm{R}_{12:}$ Non management expenses divided by total expenses (\%) & 55.0 & 4.5 & 86.9 & 52.7 & 20.9 & 94.3 \\
\hline $\mathrm{R}_{13:}$ Elite services investment divided by total expenses $(\%)$ & 5.2 & 0.0 & 67.3 & 10.8 & 0.0 & 74.8 \\
\hline $\mathrm{R}_{14:}$ Member services investment divided by total expenses (\%) & 14.2 & 0.2 & 71.1 & 14.7 & 1.7 & 76.8 \\
\hline $\mathrm{R}_{15:}$ Membership financial return (\%) & 45.2 & 0.6 & 843.9 & 47.8 & 2.2 & 383.1 \\
\hline
\end{tabular}


Table 2: Factor Analysis of the financial ratios of the French speaking sport federations for years 2001 to 2006 with the exception of 2004.

\begin{tabular}{|c|c|c|c|c|c|c|c|c|c|c|c|c|}
\hline \multirow[t]{2}{*}{ Financial ratios $\left(\mathrm{R}_{1-15}\right)$} & \multicolumn{2}{|c|}{$\begin{array}{l}\text { Public funds } \\
\text { dependence }\end{array}$} & \multicolumn{2}{|c|}{$\begin{array}{l}\text { Financial } \\
\text { balance }\end{array}$} & \multicolumn{2}{|c|}{$\begin{array}{l}\text { Attraction of } \\
\text { resources }\end{array}$} & \multicolumn{2}{|c|}{$\begin{array}{c}\text { Financial } \\
\text { budget }\end{array}$} & \multicolumn{2}{|c|}{$\begin{array}{c}\text { Member } \\
\text { services } \\
\text { investment }\end{array}$} & \multicolumn{2}{|c|}{$\begin{array}{c}\text { Elite services } \\
\text { investment }\end{array}$} \\
\hline & Min & Max & Min & Max & Min & Max & Min & $\operatorname{Max}$ & Min & Max & Min & Max \\
\hline $\mathrm{R}_{1:}$ Public resources divided by total revenue & $.95 *$ & $.97 *$ & -.10 & .09 & -.06 & -.01 & -.10 & -.04 & -.01 & .05 & -.15 & .11 \\
\hline $\mathrm{R}_{2:}$ Public resources divided by total expenses & $.79 *$ & $.96 *$ & .17 & $.54 *$ & -.11 & -.03 & -.13 & -.02 & -.01 & .08 & -.11 & .09 \\
\hline $\mathrm{R}_{3:}$ Total revenue divided by total expenses & .06 & .24 & $.90 *$ & $.99 *$ & -.05 & .04 & -.10 & -.02 & -.09 & .06 & -.03 & .05 \\
\hline $\mathrm{R}_{4 \text { : Net revenues divided by total revenue }}$ & .07 & .15 & $.94 *$ & $.99 *$ & -.04 & .08 & -.04 & .03 & -.07 & .09 & -.07 & .03 \\
\hline $\mathrm{R}_{7:}$ Grants per member & .18 & $.46^{*}$ & -.11 & -.07 & $.70 *$ & $.96 *$ & -.12 & $<.01$ & .01 & .09 & -.06 & .17 \\
\hline $\mathrm{R}_{8:}$ Total revenues per member & -.06 & .01 & .03 & .06 & $.97 *$ & $1.0 *$ & -.05 & .06 & -.01 & .04 & -.02 & .09 \\
\hline $\mathrm{R}_{9:}$ Revenues from member per member & -.39 & -.30 & .04 & .11 & $.89 *$ & $.95 *$ & -.03 & .08 & -.05 & .04 & -.05 & .02 \\
\hline $\mathrm{R}_{6:}$ Total revenues & -.19 & -.07 & -.12 & .07 & -.04 & .08 & $.90 *$ & $.98 *$ & -.07 & .05 & -.08 & .02 \\
\hline $\mathrm{R}_{11:}$ Total expenses & -.21 & -.04 & -.16 & .02 & -.05 & .06 & $.89 *$ & $.99 *$ & -.07 & .04 & -.09 & .03 \\
\hline $\mathrm{R}_{14:}$ Member services investment divided by total & -.25 & -.10 & -.07 & .17 & -.20 & -.02 & -.04 & .05 & $.83 *$ & $.94 *$ & -.23 & .15 \\
\hline $\mathrm{R}_{15:}$ Membership financial return & .22 & $.43 *$ & -.23 & $<.01$ & .09 & .25 & -.03 & .09 & $.79 *$ & $.93 *$ & -.15 & -.01 \\
\hline $\mathrm{R}_{13 \text { : Elite services investment divided by total expenses }}$ & .14 & $.61 *$ & -.18 & -.02 & .01 & .14 & -.12 & .15 & -.38 & -.18 & $.61 *$ & $.95^{*}$ \\
\hline $\mathrm{R}_{5:}$ Net revenues & -.31 & .15 & .38 & $.82 *$ & .02 & .28 & $-.45^{\#}$ & $.77 *$ & -.12 & .01 & -.27 & .04 \\
\hline $\mathrm{R}_{12 \text { : Non management expenses divided by total expenses }}$ & -.33 & -.01 & -.14 & .18 & -.08 & .04 & -.18 & .05 & .13 & $.64^{*}$ & .39 & $.97 *$ \\
\hline $\mathrm{R}_{10 \text { : Sponsorship revenue divided by total revenue }}$ & $-.43^{\#}$ & .24 & -.05 & $.46^{*}$ & -.17 & .03 & -.15 & $.65 *$ & -.08 & .39 & -.07 & $.72 *$ \\
\hline
\end{tabular}

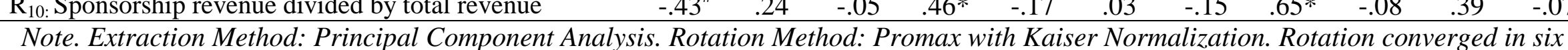

iterations for 2005; seven iterations for 2001. 2003 and 2006 and eight iterations for 2002; *Significance >.4 ; * Significance <-.4

Minimum and maximum coefficients for years 2001-2003 and 2005-2006 are presented 
Table 3: Significant correlations between financial performance-related categories from 2001 to 2006

\begin{tabular}{|c|c|c|c|c|c|c|}
\hline Financial performance-related categories correlated & 2001 & 2002 & 2003 & 2004 & 2005 & 2006 \\
\hline Public funds dependence - Elite services investment & & & $.34 *$ & $.52 * *$ & $.47 * *$ & $.38 * *$ \\
\hline Financial balance - Member services investment & & & & $-.54 * *$ & & \\
\hline Financial balance - Elite services investment & & $-.34 *$ & & $.40 * *$ & & \\
\hline Elite services investment - Member services investment & & & $-.31 *$ & $-.40 * *$ & & \\
\hline Financial balance - Attraction of resources & & & & & $.31 *$ & \\
\hline Public funds dependence - Financial budget & $-.41 * *$ & $-.28 *$ & $-.38 * *$ & $-.35^{*}$ & $-.47 * *$ & $-.38 * *$ \\
\hline Public funds dependence - Financial balance & $.34 *$ & $.51^{* *}$ & $.32 *$ & & & \\
\hline
\end{tabular}

Note. Pearson correlations (2-tailed): $*=p<.05 / * *=p<.01$ 